\title{
Inducing flowering in Noccaea caerulescens (J. \& C. Presl) F. K. Mey (Brassicaceae), a species having high heavy-metal accumulation ${ }^{1}$
}

\author{
Indução ao florescimento de Noccaea caerulescens (J. Presl \& C. Presl) F. K. Mey \\ (Brassicaceae), uma espécie hiperacumuladora de metais pesados
}

\author{
Marcelo de Almeida Guimarães ${ }^{2 *}$, Marcelo Ehlers Loureiro ${ }^{3}$ and David Edward Salt ${ }^{4}$
}

\begin{abstract}
Noccaea caerulescens (J. \& C. Presl) F. K. Mey (Brassicaceae) is a plant widely used in studies of the high accumulation of such metals as $\mathrm{Cd}, \mathrm{Ni}$, and $\mathrm{Zn}$. Considered a biennial species, propagated mainly by seed, it presents a long period for the generation of new individuals, which significantly hampers the development of new studies of this species. Based on the above, the objective of this work was to develop a protocol to induce early flowering and abundant seed-production in N. caerulescens. Plants of this species were therefore grown and developed in a controlled environment (growth room and cold chamber), and then submitted to different treatments composed of combinations of the following environmental conditions: photoperiod ( 8 or 12 hour of light $\left.-100 \mu \mathrm{mol} \mathrm{m}^{-2} \mathrm{~s}^{-1}\right)$, temperature $\left(4\right.$ or $\left.21^{\circ} \mathrm{C}\right)$, time of exposure to the above conditions ( 6 or 8 weeks) and application of different concentrations of GA3 ( $0,15,30$ and $\left.60 \mu \mathrm{g} \mu \mathrm{L}^{-1}\right)$. The work was carried out in a completely randomized design, with twenty plants per treatment being analyzed. The following characteristics were evaluated: a) Percentage of flowering (\%); (b) Length of main cluster $(\mathrm{cm})$; and (c) seed production $\left(\mathrm{g} \mathrm{pl}^{-1}\right)$. It can be seen that the temperature of $4^{\circ} \mathrm{C}$ was essential for inducing flowering and seed-production in $N$. caerulescens, with the time of exposure of the plants to this temperature being very important to potentialise seed production and longer periods of exposure to low temperatures being preferred.
\end{abstract}

Key words: Thlaspi caerulescens (J. \& C. Presl). GA . Main cluster. Seed production. Vernalization.

\begin{abstract}
RESUMO - Noccaea caerulescens (J. \& C. Presl) F. K. Mey (Brassicaceae) é uma planta muito utilizada em estudos de hiperacumulação de metais como $\mathrm{Cd}$, Ni e Zn. Considerada espécie bienal, sendo propagada basicamente por sementes, apresenta longo período de tempo para a geração de novos indivíduos, o que prejudica consideravelmente o desenvolvimento de novos estudos com esta espécie. Baseado no exposto objetivou-se neste trabalho, o desenvolvimento de um protocolo para indução de florescimento precoce e abundante de $N$. caerulescens. Para isso, plantas desta espécie foram crescidas e desenvolvidas em ambiente controlado (sala de crescimento e câmara fria), sendo então submetidas a diferentes tratamentos que eram compostos por combinações de diferentes condições ambientais: fotoperíodo ( 8 ou 12 horas de luz - $\left.100 \mu \mathrm{mol} \mathrm{m} \mathrm{m}^{-2} \mathrm{~s}^{-1}\right)$, temperatura $\left(4\right.$ ou $\left.21^{\circ} \mathrm{C}\right)$, semanas de exposição às condições de luz e temperatura citadas anteriormente (6 ou 8 semanas) e aplicação de concentrações de GA3 $\left(0 ; 15 ; 30\right.$ e $\left.60 \mu \mathrm{g}_{\mu} \mathrm{L}^{-1}\right)$. $\mathrm{O}_{\text {trabalho }}$ foi conduzido em delineamento inteiramente casualizado, sendo analisadas vinte plantas por tratamento. As seguintes características foram avaliadas: a) Percentual de florescimento (\%); b) Comprimento do pendão principal (cm); e c) Produção de sementes $\left(\mathrm{g} \mathrm{pl}^{-1}\right)$. Pode-se observar que a temperatura de $4{ }^{\circ} \mathrm{C}$ foi essencial para a indução ao florescimento e produção de sementes de $N$. caerulescens, sendo que o tempo de exposição das plantas a esta, foi muito importante para a potencialização da produção de sementes, sendo desejados períodos mais longos de exposição à baixa temperatura.
\end{abstract}

Palavras-chave: Thlaspi caerulescens (J. \& C. Presl). GA . Pendão principal. Produção de sementes. Vernalização.

\footnotetext{
* Autor para correspondência

${ }^{1}$ Recebido para publicação em 24/09/2012; aprovado em 01/07/2013

Parte da Tese do primeiro autor apresentada no Departamento de Fitotecnia/UFC, bolsista de doutorado do CNPq

2Departamento de Fitotecnia, Universidade Federal do Ceará, Fortaleza-CE, Brasil, mguimara@ ufc.br

${ }^{3}$ Departamento de Fisiologia Vegetal, Universidade Federal de Viçosa, Viçosa-MG, Brasil, mehlers@ufv.br

${ }^{4}$ Institute of Biological and Environmental Sciences, University of Aberdeen, Aberdeen, United Kingdom, david.salt@abdn.ac.uk
} 


\section{INTRODUCTION}

All plant species monitor the environment and their own internal signals in order to ensure their reproduction at the most appropriate time of the year and correct stage of development (BALASUBRAMANIAN et al., 2006; BOUVERET et al., 2006; COBBETT, 2003, PRASAD, FREITAS, 2003). Thus, the propagation and survival of a plant species depends critically on its ability to regulate with accuracy its phases of transition between vegetative and reproductive growth (KOMEDA, 2004; YANG et al., 2006).

Researchers have been able to bring forward the flowering of certain species, such as A. thaliana, T. arvense and Brassica napus, belonging to the same family as $N$. caerulescens (Brassicaceae), by modifying the photoperiod (DAHANAYAKE; GALWEY, 1999), the temperature (BALASUBRAMANIAN et al., 2006) and the application of gibberellin (DAHANAYAKE; GALWEY, 1999).

Several studies have been conducted using the species Arabidopsis thaliana, with the aim of establishing flowering pathways (AUSIN; ALONSO-BLANCO, MARTINES-ZAPATER, 2005; BERNIER; PÉRILLEUX, 2005; QUESADA, DEAN; SIMPSON, 2005). However, for other plant species, such as Noccaea caerulescens, little information is available about simulating the best conditions for producing these events.

N. caerulescens also known as Thlaspi caerulescnes (UNIPROT TAXONOMY) is considered a compact plant (PEER et al., 2003). Its leaves present an opposite arrangement, with obtuse distal and attenuated proximal parts. Its flowers are small, whitish in colour and self-pollinating (BESNARD et al., 2009). Cross-fertilization may also occur between different compatible populations (BASIC; BESNARD, 2006). The fruits are in the shape of silica, with dehiscence being seen from six to eight weeks after anthesis. Generally three to five seeds are seen per fruit. $N$. caerulescens is not grown commercially, being found in nature in many temperate regions (BESNARD et al., 2009). In recent years it has received special attention due to having been selected as a model system for molecular-genetic studies of the over-accumulation of metals by plants (PEER et al., 2003). According to several researchers, this species is able to hyperacumulate such metals as Cd, Ni and Zn (GUIMARÃES; GUSTIN; SALT, 2009; NASCIMENTO; XING, 2006). However, it has the great disadvantage of having a long life cycle (biennial plant; PEER et al., 2003), requiring two cold seasons, one for breaking seed dormancy, and the second for vernalisation, to promote flowering.

In the case of photoperiod-induced flowering, it is known to occur in the species A. thaliana by means of signals over long distances between the leaves and the apical meristem, via the phloem (BERNIER; PÉRILLEUX, 2005).

However, many temperate species (as is the case of $N$. caerulescens), only bloom after they have gone through a prolonged cold period, a process known as vernalisation, which allows for the 'alignment' of the induction of flowering and those climate conditions which are favourable for its proper development (HENDERSON; DEAN, 2004). In general, winter annuals are vernalized when at the seedling stage, while biennials require a long period of development at low temperatures in order to stimulate flowering.

According to Yamaguchi and Kamiya (2000) the environmental factors, photoperiod and temperature, can alter the levels of active gibberellins, affecting gene transcription at specific stages in the biosynthetic pathways of this hormone. The gibberellins take part in the regulation of several physiological processes, including the germination of seeds, establishing of fruit and development of flowers. However, the application of gibberellins may cause a decrease in the expression of those genes which encode the synthesis of such active gibberellins as GA20 oxidase and GA3 oxidase, and on the contrary, result in an increase in transcription of the GA2 oxidase degradation genes (ELLIOTT et al., 2001) so inhibiting flowering. The enzymes, GA20 oxidase GA3oxidase, directly participate in the formation pathways of the $\mathrm{GA}_{1 / 4}$ active gibberellines (TAIZ; ZEIGER, 2004). According Taiz and Zeiger (2004), $\mathrm{GA}_{3}$ can replace $\mathrm{GA}_{1}$ in most bioassays.

Given the above, the objective of this work was to develop a protocol for inducing early and abundant flowering in $N$. caerulescens.

\section{MATERIAL AND METHODS}

\section{Plant Material}

The original seeds of the hyperaccumulating plant, N. caerulescens St. Félix de Palliéres, came from France, as described by Peer et al. (2003).

\section{Germination}

Twenty-five seeds of $N$. caerulescens were germinated on plates $(100 \times 15 \mathrm{~mm})$ containing $0.5 \mathrm{x}$ Murashige and Skoog medium (MSP001, CAISSON Laboratories, Inc. / www.caissonlabs.com) with the further addition of vitamins (MSV11001, CAISSON Laboratories, Inc.), 1.2\% agar (ACUMEDIA manufacturers, Inc.) and $3.0 \mathrm{mg} \mathrm{l}^{-1}$ Benomyl (methyl 1-(butilcarbomil)-2benzimidazolcarbamato (SIGMA, St. Louis, MO)). After 
seeding, the plates were incubated at $4{ }^{\circ} \mathrm{C}$ for 5 days, and following this period of seed stratification, were placed vertically in an incubator under controlled conditions (16 hours light: 8 hours darkness, with temperatures ranging from $\left.18-23{ }^{\circ} \mathrm{C}\right)$. Germination occurred approximately one week after transfer.

\section{Growing conditions}

The experiment was conducted in plant growth chambers and cold rooms located on the campus of Purdue University, in West Lafayette, Indiana, USA. Seedlings at 20 days were individually transferred to $0.3 \mathrm{~L}$ pots filled with substrate (Premier Promix PGX, Canada). The plants were irrigated twice a week with a nutrient solution containing $200 \mathrm{mg} \mathrm{L}^{-1} \mathrm{~N}, 29 \mathrm{mg} \mathrm{L}^{-1} \mathrm{P}$, $167 \mathrm{mg} \mathrm{L}^{-1} \mathrm{~K}, 67 \mathrm{mg} \mathrm{L}^{-1} \mathrm{Ca}$ and $30 \mathrm{mg} \mathrm{L}^{-1} \mathrm{Mg}$, and supplied with micronutrients using a commercial formula (MiracleGro® Excel® 15-05-15 Cal-Mag; The Scotts Co, Marysville, Ohio). The $\mathrm{pH}$ of the nutrient solution was adjusted to 5.7 to 6.0 , using $0.08 \mathrm{ml}$ of $93 \%$ sulphuric acid (v/v, Ulrich Chemical, Indianapolis) per litre of solution (ASCHENBECK, EDDY, 2004). The plants were kept in a greenhouse for 8 weeks under controlled environmental conditions (12 hours light $\left(200 \mu \mathrm{mol} \mathrm{m} \mathrm{m}^{-2} \mathrm{~s}^{-1}\right)$ : 12 hours darkness, with temperatures ranging from 19 to $25^{\circ} \mathrm{C}$ ).

\section{Treatments}

The treatments were: amount of light in hours ( 8 or 12 hours $\left(100 \mu \mathrm{mol} \mathrm{m} \mathrm{m}^{-2} \mathrm{~s}^{-1}\right)$, temperature $\left(4\right.$ or $\left.21^{\circ} \mathrm{C}\right)$, weeks of exposure to the above conditions of light and temperature (6 or 8 weeks), and application of different concentrations of $\mathrm{GA}_{3}\left(0,15,30\right.$ and $\left.60 \mu \mathrm{G} \mu \mathrm{L}^{-1}\right)$. One

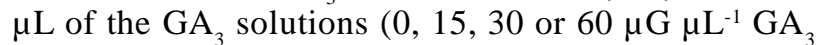
in $10 \% \mathrm{v} / \mathrm{v}$ water/acetone, with the addition of $0.05 \%$ Tween 20) were applied at the apex of the plant. There were ten applications of each solution, which were carried out on alternate days. After a period of 6 or 8 weeks of exposure to the above light and temperature conditions, the plants were transferred to new growth conditions $\left(21{ }^{\circ} \mathrm{C}, 12\right.$ hours light, $\left.200 \mu \mathrm{mol} \mathrm{m} \mathrm{m}^{-2} \mathrm{~s}^{-1}\right)$, where they remained for around 6 to 8 weeks, that is until the fruits were completely ripe. After this period, plant irrigation was stopped in order to facilitate harvesting and quantification of the seeds.

\section{Evaluated characteristics}

Flowering was evaluated at 0 and 50 days after transfer (DAT) of the plants, for the treatment conditions of $21{ }^{\circ} \mathrm{C}, 12$ hours light, $200 \mu \mathrm{mol} \mathrm{m} \mathrm{m}^{-2} \mathrm{~s}^{-1}$, by assessing the start of flowering at both the apex and central part of the plants. The height of the main tassel was determined by measuring the length from the base of the main stem to its highest point. The mass of seeds was collected about 2 weeks after stopping irrigation, when their amount was determined by collecting the seeds from each individual plant into paper bags. The seeds were separated from the other parts of the plants (stems, leaves, pods, etc) and weighed in grams per plant.

\section{Statistics}

The study was carried out employing a completely randomised design in a $2 \times 2 \times 2 \times 4$ factorial scheme: two values for the amount of light in hours ( 8 and 12 hours of light $\left(100 \mu \mathrm{mol} \mathrm{m} \mathrm{m}^{-2} \mathrm{~s}^{-1}\right)$; two temperature conditions ( 4 and $21^{\circ} \mathrm{C}$ ); two values for weeks of exposure to the above conditions of light and temperature ( 6 and 8 weeks); and the application of four different concentrations of $\mathrm{GA}_{3}(0,15,30$ and $\left.60 \mu \mathrm{G} \mu \mathrm{L}^{-1}\right)$. Twenty plants were evaluated for each treatment.

To evaluate flowering, the twenty plants from each treatment were divided into four lots of five plants, with the percentage of flowering plants being determined as the average percentage of the four lots.

The data were statistically analysed and tested for significance $(\mathrm{p} \leq 0.05)$. In order to determine the difference between treatments, the Scott-Knott test in the system for statistical analysis - SAEG (RIBEIRO JUNIOR, 2001) was used.

\section{RESULTS AND DISCUSSION}

\section{Relationship between the different treatments and flowering}

Before the transfer of those plants which had been under different environmental conditions for growth and development ( 8 or 12 hours of light per day, 4 or $21{ }^{\circ} \mathrm{C}$, and 6 or 8 weeks exposure), to the final environmental growing conditions $\left(21{ }^{\circ} \mathrm{C}, 12\right.$ hours light, $200 \mu \mathrm{mol} \mathrm{m}^{-2} \mathrm{~s}^{-1}$ ), it was found that in the treatments with low temperatures $\left(\mathrm{lt}, 4^{\circ} \mathrm{C}\right)$, regardless of the exposure time, length of day and/or concentration of applied $\mathrm{GA}_{3}$, the plants showed a higher percentage of flowering compared to those treatments conducted without low temperatures (wlt, $21^{\circ} \mathrm{C}$, table 1). These results differ from those presented by Peer et al. (2003), who found percentages for flowering of between 90 and $100 \%$, only when plants of $N$. ccaerulescens were subjected to conditions of $4{ }^{\circ} \mathrm{C}$ and 8 hours of light for a period of 10 weeks. These results suggest that vernalisation is the main controlling factor of floral induction in $N$. caerulescens, and that gibberellin is not a substitute for the low temperatures required to obtain the maximum rates for flowering. 
Table 1 - Percentage of flowering (\%) in plants of $N$. caerulescens under different periods of daily exposure to light (8 and 12 hours), temperatures $\left(4\right.$ and $\left.21^{\circ} \mathrm{C}\right)$, weeks of exposure to the above-mentioned combinations of light and temperature, and to different concentrations of gibberalin (GA) applied to the apical growth zone. Purdue University, USA, 2009

\begin{tabular}{|c|c|c|c|c|c|c|c|}
\hline & \multirow{3}{*}{$\begin{array}{l}\text { Light } \\
\text { (hours) }\end{array}$} & \multirow{3}{*}{$\begin{array}{c}\text { Temp. } \\
\left({ }^{\circ} \mathrm{C}\right)\end{array}$} & \multirow{3}{*}{$\begin{array}{c}\text { Time } \\
\text { (weeks) }\end{array}$} & \multicolumn{4}{|c|}{ Percentage flowering $(\%)$} \\
\hline & & & & \multicolumn{4}{|c|}{$\mathrm{GA}\left(\mu \mathrm{g} \mu \mathrm{L}^{-1}\right)$} \\
\hline & & & & 0 & 15 & 30 & 60 \\
\hline \multirow{6}{*}{$0 \mathrm{DAT}^{*}$} & 8 & 4 & 6 & $100 \mathrm{a}$ & $100 \mathrm{a}$ & $100 \mathrm{a}$ & $100 \mathrm{a}$ \\
\hline & 8 & 4 & 8 & $100 \mathrm{a}$ & $100 \mathrm{a}$ & $100 \mathrm{a}$ & $100 \mathrm{a}$ \\
\hline & 12 & 4 & 6 & $100 \mathrm{a}$ & $100 \mathrm{a}$ & $100 \mathrm{a}$ & $100 \mathrm{a}$ \\
\hline & 12 & 4 & 8 & $100 \mathrm{a}$ & $100 \mathrm{a}$ & $100 \mathrm{a}$ & $100 \mathrm{a}$ \\
\hline & 12 & 21 & 6 & 0 & $5 \mathrm{~b}$ & 0 & 0 \\
\hline & 12 & 21 & 8 & 0 & $10 \mathrm{~b}$ & $20 \mathrm{~b}$ & $10 \mathrm{~b}$ \\
\hline \multirow{6}{*}{$50 \mathrm{DAT}^{*}$} & 8 & 4 & 6 & $100 \mathrm{a}$ & $100 \mathrm{a}$ & $100 \mathrm{a}$ & $100 \mathrm{a}$ \\
\hline & 8 & 4 & 8 & $100 \mathrm{a}$ & $100 \mathrm{a}$ & $100 \mathrm{a}$ & $100 \mathrm{a}$ \\
\hline & 12 & 4 & 6 & $100 \mathrm{a}$ & $100 \mathrm{a}$ & $100 \mathrm{a}$ & $100 \mathrm{a}$ \\
\hline & 12 & 4 & 8 & $100 \mathrm{a}$ & $100 \mathrm{a}$ & $100 \mathrm{a}$ & $100 \mathrm{a}$ \\
\hline & 12 & 21 & 6 & 0 & $10 \mathrm{~b}$ & $18 \mathrm{~b}$ & $12 \mathrm{~b}$ \\
\hline & 12 & 21 & 8 & 0 & $22 \mathrm{~b}$ & $28 \mathrm{~b}$ & $19 \mathrm{~b}$ \\
\hline
\end{tabular}

*0 and 50 DAT - 0 and 50 days after transfer of the plants from different treatments to the same conditions of temperature $\left(21^{\circ} \mathrm{C}\right)$ and length of day (12 hours of light, $\left.200 \mu \mathrm{mol} . \mathrm{m}^{-2} \mathrm{~s}^{-1}\right) .{ }^{* *}$ Different letters in the columns indicate a statistical difference between treatments at a $5 \%$ level of significance, according to the Scott-Knott test. The Coefficient of Variation (C.V.) for flowering percentage - 13,22\%

At 50 days after transfer (50 DAT) of the plants a result similar to that observed previously was seen, however, although not statistically significant, there was a slight increase in the flowering percentage for those treatments that had not been subjected to a temperature of $4{ }^{\circ} \mathrm{C}$. This may indicate that the requirement for vernalisation is reduced based on the age of the plant, since the increase in internal gibberellin levels may play a more prominent role (Table 1).

The length of day did not affect the flowering percentage in plants at $4{ }^{\circ} \mathrm{C}$, since both plants receiving 8 hours of light and those receiving 12 hours, presented $100 \%$ flowering (Table 1). However, when at the higher temperature of $21^{\circ} \mathrm{C}$, a greater flowering percentage was seen at both 0 and 50 DAT in those plants under long-day conditions, and which received applications of $\mathrm{GA}_{3}$, ( 7.5 and $18.2 \%$ on average respectively). These results are in contrast to those presented by Dahanayake and Galwey (1999), who by the application of 10 or 40 $\mu \mathrm{g} \mu \mathrm{L}^{-1} \mathrm{GA}_{3}$ at the apex of plants of Brassica napus, were able to produce the effect of low temperatures and greater daylight time (12 hours) on the flowering of this species. For $N$. caerulescens, in the absence of low temperatures $\left(4{ }^{\circ} \mathrm{C}\right)$, the application of $\mathrm{GA}_{3}$ together with the largest photoperiod under study ( 12 hours of light) appears to promote at least partial flowering, since when they were not available, no flowering plants were observed (Table 1). GA3 therefore was not able to replace the demand for longer photoperiods (12 hours) and/or low temperatures $\left(4^{\circ} \mathrm{C}\right)$ in the flowering of this species.

One justification for the poor, or absence of, flowering in $N$. caerulescens when not under lowtemperature conditions $\left(4^{\circ} \mathrm{C}\right)$ for any length of time, may be related to the expression of the gene, FLOWERING LOCUS C (FLC). This gene is strongly expressed in the non-vernalised apical meristem of the stalk in plants of $A$. thaliana, which require a period of cold for flowering (MICHAELS; AMASINO, 2000). Several researchers have found that this gene acts as a repressor of flowering (AMASINO, 2004; D'ALOIA; TOCQUIN; PÉRILLEUX, 2008; RATCLIFFE et al., 2003), and after vernalization, the gene appears to be turned off due to the deacetylation of the chromatin resulting in a modification of its structure (AMASINO, 2004). According to Burn et al. (1993) and Finnegan et al. (1998), methylation of the DNA also causes late flowering, whereas vernalization in such plants as Arabidopsis and T. arvense was effective in promoting demethylation in these species, and encourage flowering. 


\section{Relationship between the different treatments and the height of the main tassel}

At 0 DAT, it can be seen that those plants under treatments conducted at a temperature of $21^{\circ} \mathrm{C}$ showed the greatest height for the main tassel $(8.5 \mathrm{~cm}$ on average, Table 2) when compared to plants at a temperature of $4{ }^{\circ} \mathrm{C}$ $(2.1 \mathrm{~cm}$ on average). This result can be attributed mainly to the fact that at a temperature of $21{ }^{\circ} \mathrm{C}$ the metabolic activity of the plants remains high, with no change in the process of cell division and differentiation, nor in the assimilation and transformation of atmospheric $\mathrm{CO}_{2}$ into carbohydrates within the plants, thereby affording their continuous growth and development. This was not observed in plants at a temperature of $4{ }^{\circ} \mathrm{C}$, mainly due to a reduction in metabolic activity caused by low temperatures, which changes the optimal configuration for the action of those enzymes present in various metabolic processes of the plant. This change culminates in a reduction of photosynthetic activity and cell division, which causes a decrease in the rate of growth and development of the plants (BUCHANAN, GRUISSEM, JONES, 2001; TAIZ; ZEIGER, 2004).

However, at 50 DAT, all the treatments at a temperature of $4{ }^{\circ} \mathrm{C}$ showed greater height for the main tassel (34.8 $\mathrm{cm}$ on average) than did plants which were kept at a temperature of $21{ }^{\circ} \mathrm{C}(11.1 \mathrm{~cm}$ on average $)$. Metzger (1985) obtained similar results for T. arvense, finding that prolonged treatments at $4{ }^{\circ} \mathrm{C}$ were necessary to stimulate growth of the main tassel in that species. According to Hazebroek and Metzger (1990), in the absence of cold there is a large accumulation of entkaurenoic acid at the stem apices, the area where the stimulus to cold is perceived. After this treatment, and a return to high temperatures, the ent-kaurenoic acid is converted to gibberellin which, according to Taiz and Zeiger (2004), stimulates cell elongation and division. Such information allows the supposition that the greater size of the main tassel, seen in plants of $N$. caerulescens at $4{ }^{\circ} \mathrm{C}$ when compared to those at $21{ }^{\circ} \mathrm{C}$, may be due primarily to the presence of higher endogenous concentrations of gibberellins in their stem apices.

In table 2 , it can be noted that the application of $\mathrm{GA}_{3}$ associated with 12 hours of light at $21{ }^{\circ} \mathrm{C}$, has an influence on the height of the main tassel of the plants at 0 DAT, with a greater average height for the main tassel $(12.4 \mathrm{~cm})$ being recorded in plants under these conditions. Plants receiving $\mathrm{GA}_{3}$ application, under conditions of 8 hours light and temperatures of $21^{\circ} \mathrm{C}$, reached an average height of $7.3 \mathrm{~cm}$, and those under conditions of 8 or 12

Table 2 - Average length of the main tassel in plants of N.caerulescens under different periods of daily exposure to light (8 and 12 hours), temperatures $\left(4\right.$ and $21^{\circ} \mathrm{C}$ ), weeks of exposure to the above-mentioned combinations of light and temperature, and to different concentrations of gibberalin (GA) applied to the apical growth zone. Purdue University, USA, 2009

\begin{tabular}{|c|c|c|c|c|c|c|c|}
\hline & \multirow{3}{*}{$\begin{array}{l}\text { Light } \\
\text { (hours) }\end{array}$} & \multirow{3}{*}{$\begin{array}{c}\text { Temp. } \\
\left({ }^{\circ} \mathrm{C}\right)\end{array}$} & \multirow{3}{*}{$\begin{array}{c}\text { Time } \\
\text { (weeks) }\end{array}$} & \multicolumn{4}{|c|}{ Length of main tassel $(\mathrm{cm})$} \\
\hline & & & & \multicolumn{4}{|c|}{$\mathrm{GA}\left(\mu \mathrm{g} \mu \mathrm{L}^{-1}\right)$} \\
\hline & & & & 0 & 15 & 30 & 60 \\
\hline \multirow{6}{*}{$0 \mathrm{DAT}^{*}$} & 8 & 4 & 6 & $1.59 \mathrm{~d}$ & $2.07 \mathrm{e}$ & $2.02 \mathrm{~d}$ & $2.05 \mathrm{e}$ \\
\hline & 8 & 4 & 8 & $1.35 \mathrm{~d}$ & $2.01 \mathrm{e}$ & $2.11 \mathrm{~d}$ & $2.10 \mathrm{e}$ \\
\hline & 12 & 4 & 6 & $3.57 \mathrm{c}$ & $7.09 \mathrm{~d}$ & $7.12 \mathrm{c}$ & $5.71 \mathrm{~d}$ \\
\hline & 12 & 4 & 8 & $3.07 \mathrm{c}$ & $8.50 \mathrm{c}$ & $7.46 \mathrm{c}$ & $8.01 \mathrm{c}$ \\
\hline & 12 & 21 & 6 & $4.24 \mathrm{~b}$ & $10.22 \mathrm{~b}$ & $11.56 \mathrm{~b}$ & $11.94 \mathrm{~b}$ \\
\hline & 12 & 21 & 8 & $6.38 \mathrm{a}$ & $12.83 \mathrm{a}$ & $14.07 \mathrm{a}$ & $13.57 \mathrm{a}$ \\
\hline \multirow{6}{*}{$50 \mathrm{DAT}^{*}$} & 8 & 4 & 6 & $31.17 \mathrm{a}$ & $34.30 \mathrm{a}$ & $35.04 \mathrm{a}$ & $36.08 \mathrm{a}$ \\
\hline & 8 & 4 & 8 & $28.01 \mathrm{a}$ & $35.61 \mathrm{a}$ & $35.47 \mathrm{a}$ & $38.10 \mathrm{a}$ \\
\hline & 12 & 4 & 6 & $5.18 \mathrm{~b}$ & $9.75 \mathrm{~d}$ & $9.83 \mathrm{c}$ & $8.88 \mathrm{~d}$ \\
\hline & 12 & 4 & 8 & $4.00 \mathrm{~b}$ & $12.80 \mathrm{c}$ & $10.03 \mathrm{c}$ & $11.97 \mathrm{c}$ \\
\hline & 12 & 21 & 6 & $6.14 b$ & $14.28 \mathrm{~b}$ & $16.27 \mathrm{~b}$ & $16.62 \mathrm{~b}$ \\
\hline & 12 & 21 & 8 & $7.33 \mathrm{~b}$ & $14.11 \mathrm{~b}$ & $15.73 \mathrm{~b}$ & $15.12 \mathrm{~b}$ \\
\hline
\end{tabular}

* 0 and 50 DAT - 0 and 50 days after transfer of the plants from different treatments to the same conditions of temperature $\left(21^{\circ} \mathrm{C}\right)$ and length of day (12 hours of light, $200 \mu \mathrm{mol} . \mathrm{m}^{-2} \mathrm{~s}^{-1}$ ). ${ }^{* *}$ Different letters in the columns indicate a statistical difference between treatments at a $5 \%$ level of significance, according to the Scott-Knott test. The Coefficient of Variation (C.V.) for flowering percentage - 11,22\% 
hours light at $4{ }^{\circ} \mathrm{C}$, with or without $\mathrm{GA}_{3}$, reached an average height of $2.1 \mathrm{~cm}$.

In contrast to those seen at 0 DAT, at 50 DAT (Table 2), the greatest heights for the main tassel were recorded in those treatments at $4{ }^{\circ} \mathrm{C}(34.8 \mathrm{~cm}$ on average), thereby highlighting the greater heights for the main tassel in treatments with the application of $\mathrm{GA}_{3}$, compared to treatments without $\mathrm{GA}_{3}$ (36.1 to $30.6 \mathrm{~cm}$ on average respectively).

At 50 DAT, the greater height for the main tassel, which was observed in the treatments at $4{ }^{\circ} \mathrm{C}$, was mainly due to the flowering of the plants of $N$. caerulescens, which, after being subjected to $\mathrm{lt}$, possibly had their endogenous concentrations of gibberellin increased, stimulating cell elongation and division as well as the transition from the juvenile to the mature stage of the plant (TAIZ; ZEIGER, 2004). Such results are an indication that the stimuli that control the level of flowering when the plants are young (0 DAT), may not work in the same way when they are more mature. It can be seen that young plants have opposing responses as regards the effects of the treatments on flowering and tassel elongation, while at 50 DAT, the stimuli have a similar effect on both.

\section{Relationship between the different treatments and seed production}

According to that seen in this study, $N$. caerulescens requires low temperatures $\left(4^{\circ} \mathrm{C}\right)$ as a necessity in order to be stimulated to produce seeds (Figure 1). Additionally, longer exposure to low temperature conditions $\left(4^{\circ} \mathrm{C}\right)$, resulted in an increase on average of $60 \%$ in seed production per plant. In contrast, applications of $\mathrm{GA}_{3}$, besides not promoting a significant increase in seed production when applied at a concentration of $60 \mu \mathrm{g} \mu \mathrm{L}^{-1}$, caused a reduction in seed production, even when the plants were subjected to longer periods of exposure to low temperatures $\left(4^{\circ} \mathrm{C}\right)$.

There is little literature available which links vernalization and/or the application of gibberellins with the level of seed production. Walenta et al. (2002) found that the species Aegilops cylindrica L. AEGCY and Triticum aestivum L. "Madsen" produced a larger

Figure 1 - Seed production (g) in plants of $N$. caerulescens under different periods of daily exposure to light (8 (dc) and 12 (dl) hours), temperatures (4 (lt) and 21 (wlt) ${ }^{\circ} \mathrm{C}$ ), weeks of exposure to the above-mentioned combinations of light and temperature (6 (6w) and 8 (8w) weeks) and to different concentrations of gibberalin $\left(\mathrm{GA}_{3}\right)$ applied to the apical growth zone. Purdue University, USA, 2009

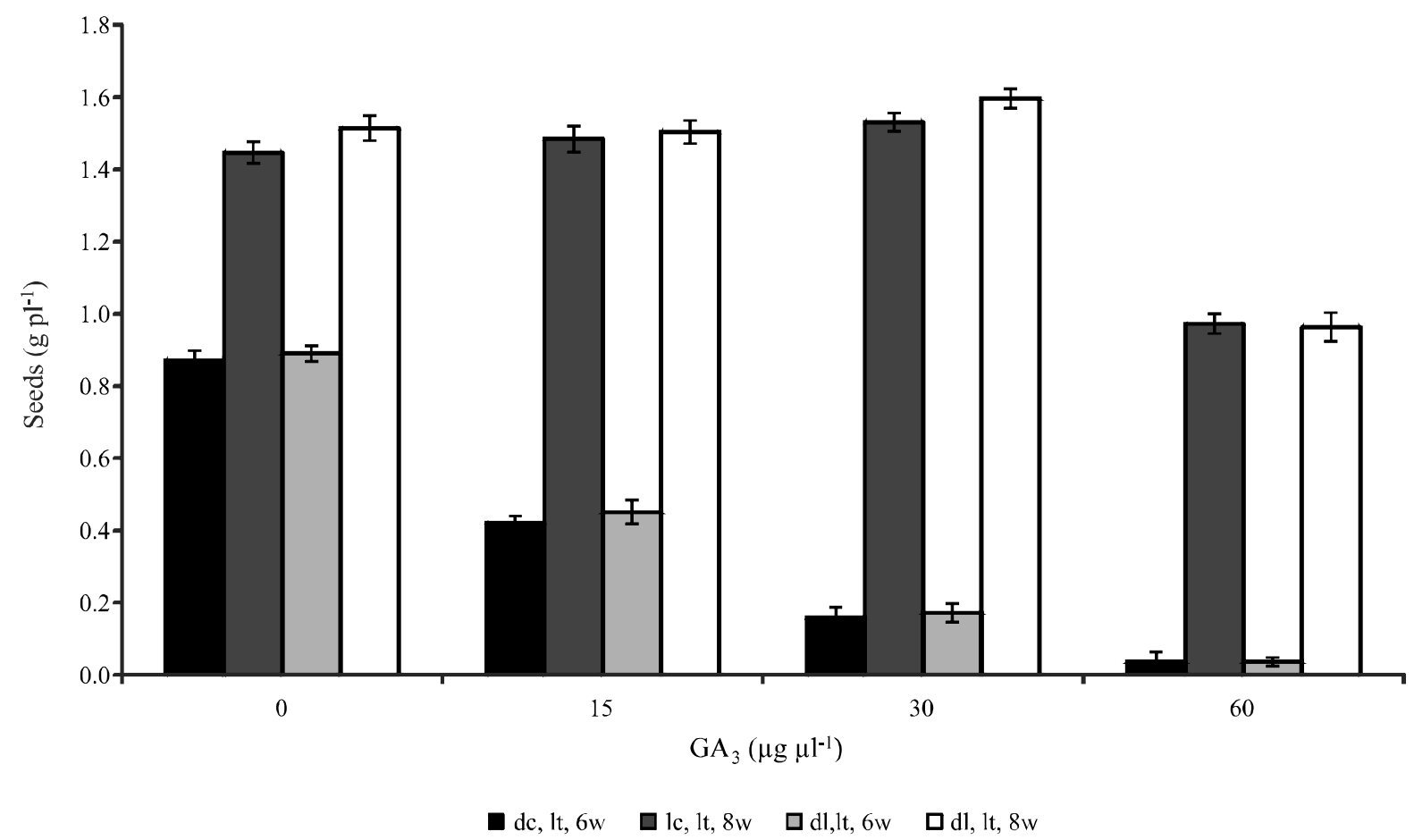

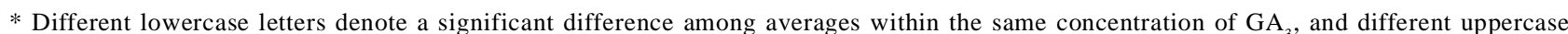
letters denote significant differences among averages within the same growing condition, both at a $5 \%$ level of significance, according to the Scott-Knott test. The Coefficient of Variation (C.V.) for flowering percentage - $11.22 \%$ 
quantity of seeds when subjected to vernalization at $4{ }^{\circ} \mathrm{C}$ for 10 weeks. However, according to these researchers, the former of the two species is less dependent on vernalization for seed production, being considered a facultative winter annual, different from the latter which is dependent on vernalization for flowering, and is not considered a facultative plant. Although not belonging to the same family as the species cited by Walenta et al. (2002), N. caerulescens shows similar behaviour to T. aestivum, and can be considered a non-facultative winter biennial, since it needs a certain period at low temperature both to germinate and to flower.

\section{CONCLUSIONS}

1. Low temperatures $\left(4{ }^{\circ} \mathrm{C}\right)$ are essential for the induction of flowering and the production of seeds in de N. caerulescens;

2. $\mathrm{GA}_{3}$, together with a long day (12 hours of light),in more mature plants, can provide a slight increase in the degree of flowering, not being effective however, in the production of seeds in $N$. caerulescens;

3. $\mathrm{GA}_{3}$ causes an increase in main tassel length in plants exposed to both short or long days, this effect only being observed in plants of $N$. caerulescens which were not under low temperatures $\left(21^{\circ} \mathrm{C}\right)$;

4. The exposure time of the plants to low temperatures $\left(4{ }^{\circ} \mathrm{C}\right)$ is very important in enhancing seed production in $N$. caerulescens, with longer exposure times being suggested;

5. The application of $\mathrm{GA}_{3}$ at high levels adversely affects seed production in $N$. caerulescens under short days ( 8 hours of light).

\section{ACKNOWLEDGMENTS}

Conselho Nacional de Desenvolvimento Científico e Tecnológico (CNPq) for the provision of scholarships and airfare for this work.

\section{REFERENCES}

AMASINO, R. Take a cold flower. Nature Genetics, v. 36, p. 111-112, 2004.

ASCHENBECK, L.; EDDY, R. Growth of Arabidopsis seedlings under differing irrigation and fertilization methods. Indiana: Purdue University, West Lafayette, 2004. Available in: <http://www.hort.purdue.edu/hort/facilities/ downloads/101materials Methods.pdf>. Accessed: 3 jan. $2013.7 \mathrm{p}$.

AUSÍN, I.; ALONSO-BLANCO, C.; MARTÍNES-ZAPATER, J. M. Environmental regulation of flowering. International Journal of Developmental Biology, v. 49, n. 5/6, p. 689705, 2005.

BALASUBRAMANIAN, S. et al. Potent induction of Arabidopsis thaliana flowering by elevated growth temperature. PlosGenetics, v. 2, n. 7, p. 980-989, 2006.

BASIC, N.; BESNARD, G. Gene polymorphisms for elucidating the genetic structure of the heavy-metal hyperaccumulating trait in Thlaspi caerulescens J. \& C. Presl and their cross-genera amplification in Brassicaceae. Journal of Plant Research, v. 119, n. 5, p. 479-487, 2006.

BERNIER, G.; PÉRILLEUX, C. A physiological overview of the genetics of flowering time control. Plant Biotechnology Journal, v. 3, n. 1, p. 03-16, 2005.

BESNARD, G. et al. Thlaspi caerulescens (Brassicaceae) population genetics in western Switzerland: is the genetic structure affected by natural variation of soil heavy metal concentrations?. New Phytologist, v. 181, n. 4, p. 974-984, 2009.

BOUVERET, R. et al. Regulation of flowering time by Arabidopsis MSI1. Development, v. 133, n. 9, p. 1693-1702, 2006.

BUCHANAN, B.; GRUISSEM, W.; JONES, R. (Eds). Biochemistry \& Molecular Biology of Plants. Rockville: American Society of Plant Physiologists, 2001. 1367 p.

BURN, J. E. et al. DNA methylation, vernalization, and initiation of flowering. Proceedings of the National Academy of Science, v. 90, n. 1, p. 287-291, 1993.

COBBETT, C. Heavy metals and plants - model systems and hyperacumulators. New Phytologist, v. 159, p. 289-293, 2003.

DAHANAYAKE, S. R.; GALWEY, N. W. Effects of interactions between low-temperature treatments, gibberellins $\left(\mathrm{GA}_{3}\right)$ and photoperiod on flowering and stem height of spring rape (Brassica napus var. annua). Annals of Botany, v. 84 , n. 3 , p. 321-327, 1999.

D’ALOIA, M.; TOCQUIN, P.; PÉRILLEUX, C. Vernalizationinduced repression of FLOWERING LOCUS C stimulates flowering in Sinapsis alba and enhances plant responsiveness to photoperiod. New Phytologist, v. 178, n. 4, p. 755-765, 2008.

ELLIOTT, R. C. et al. Feed-forward regulation of gibberellins deactivation in pea. Journal of Plant Growth Regulation, v. 20, n. 1 , p. $87-94,2001$.

FINNEGAN, E. J. et al. DNA methylation and the promotion of flowering by vernalization. Proceedings of the National Academy of Science, v. 95, n. 10, p. 5824-5829, 1998.

GUIMARÃES, M. A.; GUSTIN, J. L.; SALT, D. E. Reciprocal grafting separates the roles of the root and shoot in zinc hyperaccumulation in Thlaspi caerulescens. New Phytologist, v. 184, n. 2, p. 323-329, 2009. 
HAZEBROEK, J. P.; METZGER, J.D. Thermoinductive regulation of gibberellin metabolism in Thlaspi arvense L. Plant Physiology, v. 94, n. 1, p. 157-165, 1990.

HENDERSON, I. R.; DEAN, C. Control of Arabidopsis flowering: the chill before the bloom. Development, v. 131, n. 16, p. 3829-3838, 2004.

KOMEDA, Y. Genetic regulation of time to flower in Arabidopsis thaliana. Annual Review of Plant Biology, v. 55, p. 521-535, 2004.

METZGER, J. D. Role of gibberellins in the environmental control of stem growth in Thlaspi arvense L. Plant Physiology, v. 78, n. 1, p. $8-13,1985$.

MICHAELS, S. D.; AMASINO, R. M. Memories of winter: vernalization and the competence to flower. Plant, Cell and Environment, v. 23, n. 11, p. 1145-1153, 2000.

NASCIMENTO, C. W. A.; XING, B. Phytoextraction: A review on enhanced metal availability and plant accumulation. Scientia Agricola, v. 63, n. 3, p. 299-311, 2006.

PEER, W. A. et al. Identifying model metal hyperaccumulating plants: germplasm analysis of 20 Brassicaceae accessions from a wide geographical area. New Phytologist, v. 159, n. 2, p. 421-430, 2003.

PRASAD, M. N. V.; FREITAS, H. M. O. Metal hyperaccumulation in plants - Biodiversity prospecting for phytoremediation technology. Eletronic Journal of Biotechnology, v. 6, n. 3, p. 285-321, 2003.
QUESADA, V.; DEAN, C.; SIMPSON, G. G. Regulated RNA processing in the control of Arabidopsis flowering. International Journal of Developmental Biology, v. 49, n. 5, p. 773-780, 2005.

RATCLIFFE, O. J. et al. Analysis of the Arabidopsis MADS AFFECTING FLOWERING Gene Family: MAF2 prevents vernalization by short periods of cold. The Plant Cell, v. 15, n. 5, p. 1159-1169, 2003.

RIBEIRO JÚNIOR, J. I. Análises estatísticas no SAEG. Viçosa: UFV, 2001. $301 \mathrm{p}$.

TAIZ L.; ZEIGER E. Fisiologia Vegetal. 3. ed. Porto Alegre: Artmed, 2004. 719 p.

UNIPROT TAXONOMY. Species Noccaea caerulescens (Alpine penny-cress) (Thlaspi caerulescens). Available in: <http://www.uniprot.org/taxonomy/107243>. Accessed: 16 de julho de 2013.

WALENTA, D. L. et al. Vernalization response of plants grown from spikelets of spring and fall cohorts of jointed goatgrass. Weed Science, v. 50, n. 4, p. 461-465, 2002.

YAMAGUCHI, S.; KAMIYA, Y. Gibberellin biosynthesis: Its regulation by endogenous and environmental signals. Plant Cell Physiology, v. 41, n. 3, p, 251-257, 2000.

YAN, L. et al. The wheat and barley vernalization gene VRN3 is an orthologue of FT. Proceedings of the National Academy of Science, v. 103, n. 51, p. 19581-19586, 2006. 